УДК $911.52(470.32)$

DOI 10.18413/2712-7443-2020-44-1-29-40

\title{
Региональные особенности литоландшафтогенеза Центрального Черноземья
}

\author{
В.Б. Михно, О.П. Быковская, А.С. Горбунов \\ Воронежский государственный университет \\ Россия, 394018, г. Воронеж, Университетская пл., 1 \\ E-mail: gorbunov.ol@mail.ru
}

\begin{abstract}
Аннотация. Литоландшафтогенез играет важную роль в формировании, трансформации и дифференциации ландшафтов. Несмотря на свою ландшафтообразующую значимость, этот процесс изучен недостаточно, что предопределило необходимость рассмотрения ландшафтообразующей роли литогенной основы Центрального Черноземья. В связи с этим авторами обосновано выделение карбонатного и силикатного типов литоландшафтогенеза, показана их специфика и пространственная дифференциация. Проведено картографирование основных морфологических типов литогенных ландшафтов. Установлены их площадные соотношения. Рассмотрена структурно-генетическая организация литогенной основы, выполнена классификация ее структурных элементов. Показаны некоторые особенности формирования региональных и типологических ландшафтных комплексов при различных физико-механических и химических свойствах горных пород. Подчеркнута ведущая роль литогенной основы в формировании ландшафтного разнообразия и поддержании оптимального ландшафтноэкологического состояния, что важно учитывать при решении задач, связанных с природопользованием в Центральном Черноземье.
\end{abstract}

Ключевые слова: ландшафтогенез, литоландшафтогенез, литогенная основа, литогенные ландшафты, классификация, дифференциация ландшафтов, Центральное Черноземье.

Благодарности: исследование проведено при финансовой поддержке РФФИ (проект 19-45360005 p_a)

Для цитирования: Михно В.Б., Быковская О.П., Горбунов А.С. 2020. Региональные особенности литоландшафтогенеза Центрального Черноземья. Региональные геосистемы. 44(1): 29-40.

DOI: $10.18413 / 2712-7443-2020-44-1-29-40$

\section{Regional features of lithological genesis of landscapes of the Central Chernozems region}

\author{
Vladimir B. Mihno, Ol'ga P. Bykovskaya, Anatoliy S. Gorbunov \\ Voronezh State University \\ 1 Universitetskaya pl., Voronezh, 394018, Russia \\ E-mail: gorbunov.ol@mail.ru
}

\begin{abstract}
The lithological genesis of landscapes plays an important role in the formation, transformation and differentiation of landscapes. The purpose of the study is to analyze the role of the lithogenic basis in formation of landscapes of the Central Chernozemic Region. The major factor in formation of the lithogenic basis is a process of lithogenesis. It's associated with marine transgressions, cover glaciations, river activity and physical and chemical weathering. The carbonate and silicate types of lithological genesis of landscapes is substantiated. Its specificity and spatial differentiation are shown. The main morphological types of landscapes with different lithogenic basis are mapped. The area of landscapes with clay-loamy, sandy, chalky, limestone and sandstone have been established. The dominant influence of the silicate type of lithological genesis of landscapes in the formation of the region's geosystems is
\end{abstract}


shown (the proportion of landscapes with clay-loamy and sandy lithogenic base is $93.3 \%$ ). The structural genetic organization of the lithogenic basis of landscapes is considered, and the classification of its structural elements is created. The division, classes, types, orders, variants and species of lithogenic basis of landscapes are identified. Some features of the formation of regional and typological landscapes with various physical, mechanical and chemical properties of rocks are shown. The attention is focused on the major role of the lithogenic base in the formation of landscape diversity and the maintenance of the optimal landscape-ecological condition. This is important in solving problems to nature management in the Central Chernozemic Region.

Keywords: landscape genesis, lithological genesis of landscapes, lithogenic basis, lithogenic landscapes, classification, landscape differentiation, Central Chernozems Region.

Acknowledgements: the research was conducted with the financial support of the RFBR (project 19-45360005 r_a).

For citation: Mihno V.B., Bykovskaya O.P., Gorbunov A.S. 2020. Regional features of lithological genesis of landscapes of the Central Chernozems Region. Regional Geosystems, 44(1): 29-40. DOI: 10.18413/2712-7443-2020-44-1-29-40

\section{Введение}

Происхождение, развитие, структурно-динамическая организация и устойчивость ландшафтов Центрального Черноземья во многом зависят от литогенной основы, которую обычно понимают как комплекс геолого-геоморфологических особенностей территории, включая стратиграфию и литологию горных пород, древнюю и новейшую тектонику, современные тектонические движения, рельеф поверхности.

Ландшафтообразующая роль литогенной основы региона в зависимости от ее горных пород, положения в рельефе и соотношения с интеграциями основных источников развития современных ландшафтов изменяется в широких пределах - от ведущей до подчиненной. В том случае, когда литогенный фактор предопределяет происхождение и развитие ландшафтных комплексов, формируются своеобразные литогенные (петрогенные) ландшафты [Мильков, 1977].

Основным звеном этого процесса выступает литоландшафтогенез, созидательная роль которого тесно зависит от геолого-геоморфологических условий территории, литологических особенностей, физико-механических и химических свойств горных пород, образующих литогенную основу ландшафтов.

Анализ строения литогенной основы свидетельствует о ее достаточно сложной структурно-генетической организации. Свойственный ей карбонатный и силикатный литоландшафтогенез выступает важнейшим фактором формирования, дифференциации и разнообразия ландшафтных комплексов, оказывает мощное воздействие на ландшафтноэкологическую обстановку. Учет этого приобретает особую значимость в связи с необходимостью совершенствования системы природопользования, осуществления территориального планирования и оптимизации ландшафтов.

Установление структурно-генетической организации литогенной основы и ее ландшафтообразующей роли может представлять интерес с точки зрения физикогеографического районирования и ландшафтного картографирования, прогнозирования и управления развитием природной среды Центрального Черноземья.

Литоландшафтогенез играет важную роль в формировании, трансформации и дифференциации ландшафтов Центрального Черноземья. Несмотря на свою ландшафтообразующую значимость, этот процесс изучен недостаточно. В результате затруднено решение ряда задач, связанных прежде всего с совершенствованием системы природопользования и оптимизации ландшафтно-экологической обстановки региона. В связи с этим авторами поставлена цель проанализировать особенности литоландшафтогенеза в Центральном Черноземье. 


\section{Объекты и методы исследования}

При осуществлении исследований литоландшафтогенез рассматривался как процесс, предопределяющий происхождение и развитие ландшафтных комплексов под воздействием литогенных факторов [Михно, 1999]. Вместе с тем учитывались наиболее устоявшиеся взгляды на ландшафтообразующую роль литогенной основы [Мильков, 1986; Солнцев, 2001], а также принимались во внимание данные, полученные в результате анализа литоландшафтогенеза ледниковых отложений и мело-мергельных горных пород [Быковская и др., 2015; Михно, Горбунов, 2019].

Получение необходимой информации о литологических особенностях, физикомеханических и химических свойствах горных пород, образующих литогенную основу ландшафтов, осуществлялись на основе полевых исследований с применением крупномасштабного ландшафтного картографирования, использования материалов геологогеоморфологических изысканий и ландшафтно-индикационных исследований.

В качестве базовой методологической основы был избран геосистемный подход со свойственными ему методами исследований - картографическим, системным, балансовым, моделирования и др. Особое значение придавалось установлению взаимодействия литогенного фактора на физико-географические процессы и компоненты ландшафтных комплексов, выявлению структурно-генетических элементов литогенной основы, определению их роли в формировании ландшафтов Центрального Черноземья.

\section{Результаты и их обсуждение}

Строение и ландшафтообразующая роль литогенной основы. Литогенная основа ландшафтов Центрального Черноземья включает верхнюю толщу горных пород - современную кору выветривания. Мощность ее варьирует в широких пределах: от нескольких сантиметров в местах обнажающихся плотных горных пород до 30-40 м на территории, перекрытой рыхлыми преимущественно песчано-глинистыми отложениями. Условно нижнюю границу современной коры выветривания (литогенной основы) совмещают с водоупорным горизонтом грунтовых вод. По существу литогенная основа - это зона наиболее активного гипергенеза. В условиях наземного варианта ландшафтной сферы она включает биопедогенный (биокосный), литогенный и литогидрогенный геогоризонты [Николаев, 2006].

Современная кора выветривания Центрального Черноземья неоднородна в литологическом отношении. Своим происхождением она обязана преимущественно литогенезу совокупности природных процессов образования и последующих изменений осадочных горных пород. Связь литогенеза с физико-географической обстановкой на широком региональном фоне детально раскрыта в специальной литературе [Страхов, 1960]. Распространение осадочных горных пород, принимающих участие в строении и развитии ландшафтов Центрального Черноземья, связано с морскими трансгрессиями, покровными оледенениями, деятельностью рек, физическим и химическим выветриванием.

В строении фундамента ландшафтных комплексов региона принимают участие две основные группы осадочных горных пород: карбонатные и силикатные. Первые из них включают известняк, доломит, мел, мергель; вторые представлены глинами, суглинками, песками, песчаником и гранитом. Карбонатные и силикатные породы предопределили особенности строения и ландшафтообразующей роли литогенной основы, обусловили формирование и дифференциацию ландшафтов (рис., табл. 1.).

Ландиафтогенез карбонатной литогенной основы. Ландшафтогенез Центрального Черноземья тесно связан с широким распространением карбонатных горных пород, образующих литогенную основу значительной части данного региона. По своему литологическому составу карбонатные породы неоднородны. Доминируют известняки и меломергельные породы. 
Известняки в пределах Центрального Черноземья обнажаются или близко залегают от поверхности на территории Среднерусской возвышенности севернее линии Курска и Воронежа. Своим происхождением они обязаны существовавшему здесь в палеозое морскому режиму, отмиранию морских растений и животных. Обнажающиеся отложения верхнедевонского возраста представлены франским и фаменским ярусами, в структуре которых принимают участие слои известняков, отличающихся литологическим составом, характером структуры и текстуры. Общая мощность их возрастает от нескольких метров на юге до 80-100 м на севере региона. Химический состав пород близок к теоретическому составу кальцита $\left(56 \% \mathrm{CaO}\right.$ и $\left.44 \% \mathrm{CO}_{2}\right)$.

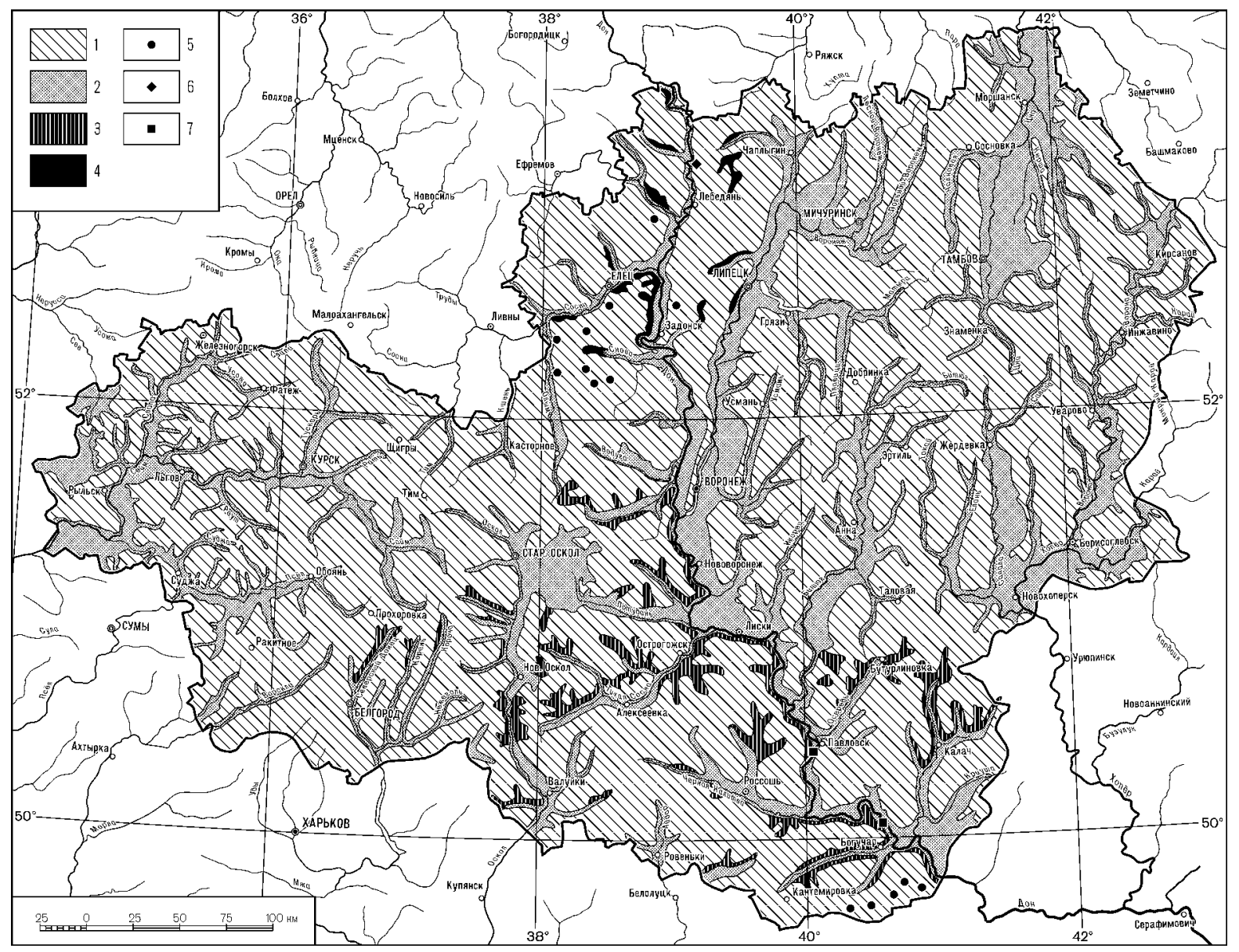

Литогенная основа ландшафтов Центрального Черноземья: 1 - водораздельные и склоновые ландшафты с глинисто-суглинистой литогенной основой; 2 - водораздельные, пойменные и надпойменно-террасовые ландшафты с песчаной и песчано-суглинистой литогенной основой; 3 - склоновые ландшафты с мело-мергельной литогенной основой; 4 - склоновые ландшафты с известняковой литогенной основой; 5 - водораздельные и склоновые ландшафты с песчаниковой литогенной основой; 6 - склоновые ландшафты с доломитовой литогенной основой; 7 - пойменные ландшафты с гранитной литогенной основой

Lithogenic basis of landscapes of the Central Chernozems Region: 1 - interfluve and slope landscapes with clay-loamy lithogenic basis; 2 - interfluve, floodplain and terrace landscapes with sandy and sandy-loamy lithogenic basis; 3 - slop landscapes with a cretaceous lithogenic basis; 4 - slope landscapes with limestone lithogenic basis; 5 - interfluve and slope landscapes with sandstone lithogenic basis; 6 - slope landscapes with dolomite lithogenic basis; 7 - floodplain landscapes with granite lithogenic basis. 
Таблица 1

Table 1

Площади ландшафтов с различной литогенной основой

Landscapes areas with different lithogenic basis

\begin{tabular}{|c|c|c|c|}
\hline № & Ландшафты & Площадь, км² & $\begin{array}{c}\text { Доля от площади } \\
\text { региона, \% }\end{array}$ \\
\hline 1 & Водораздельные глинисто-суглинистые & 83328,49 & 49,8 \\
\hline 2 & Надпойменно-террасовые песчаные & 17700,74 & 10,6 \\
\hline 3 & Водораздельные и склоновые суглинисто-песчаниковые & 316,54 & 0,2 \\
\hline 4 & Водораздельные песчаные & 4239,32 & 2,5 \\
\hline 5 & Склоновые меловые и суглинисто-меловые & 10580,35 & 6,3 \\
\hline 6 & Склоновые суглинисто-известняковые & 702,51 & 0,4 \\
\hline 7 & Склоновые песчаные и песчано-суглинистые & 2594,75 & 1,6 \\
\hline 8 & Склоновые глинисто-суглинистые & 17827,97 & 10,7 \\
\hline \multirow[t]{2}{*}{9} & Пойменные и постпойменные песчано-суглинистые & 29988,85 & 17,9 \\
\hline & Итого & 167279,52 & 100 \\
\hline
\end{tabular}

Мело-мергельные породы распространены в южной части Среднерусской возвышенности и на Калачской возвышенности - к югу от линии Курск - Воронеж - Лиски Таловая. Обнажения мело-мергельных пород особенно часты по крутым побережьям Дона, Тихой Сосны, Потудани, Оскола, Сейма, Псёла, Северского Донца и других рек. Многочисленные меловые обнажения также приурочены к балкам, оврагам и карьерам. Общая площадь обнажающихся мело-мергельных пород в пределах Среднерусской и Калачской возвышенностях составляет около 1,5 млн га.

Происхождение мело-мергельных пород региона тесно связано с верхнемеловой трансгрессией. Карбонатные породы верхнемелового возраста приурочены к туронскому, коньякскому, сантонскому, кампанскому и маастрихскому ярусам Воронежской антеклизы, образуя самостоятельный структурный этаж, мощность которого возрастает от нескольких метров у северной границы распространения мело-мергельных пород до 200250 м на юге Центрального Черноземья. Литология, стратиграфия, тектоника и особенности формирования меловых отложений региона нашли отражение в ряде работ [Савко и др., 2001; Дмитриев и др., 2004; Иванова, Савко, 2011].

Ландшафтообразующая роль карбонатной литогенной основы на территории рассматриваемого региона проявляется неодинаково и зависит прежде всего от физикомеханических и химических свойств ее горных пород, обуславливающих своеобразие энерго- и массообмена, лежащих в основе ландшафтогенеза. Карбонатные породы здесь обладают достаточно высокой интенсивностью ландшафтообразования. Об этом свидетельствует сильная подверженность их физической и химической денудации (эрозия, карст), изменяющей рельеф местности и трансформирующей ландшафты, а также усиливающей контрастность сред и процессы переноса вещества, в том числе типоморфного элемента кальция в виде $\mathrm{CaCO}_{3}$.

Интенсивная миграция и значительная аккумуляция кальция свойственна всем ландшафтным комплексам региона, имеющим карбонатную литогенную основу. Это позволяет отнести их к классу кальциевых ландшафтов [Перельман, 1975]. 
По соотношению химической и механической денудации, разнообразию и контрастности, устойчивости ландшафты, сформировавшиеся на известняках и меломергельных породах, отличаются, образуя два типа ландшафтов: известняково-карстовые и карстово-меловые [Известняковый..., 1978; Михно, 1990]. В целом кальцефитным ландшафтам Центрального Черноземья присущи ослабленное проявление зональных признаков, морфолого-генетическое разнообразие, повышенная динамичность, подверженность карстовой денудации.

Ландшафтогенез силикатной литогенной основы. В строении литогенной основы ландшафтов большей части территории Центрального Черноземья принимают силикатные горные породы со свойственным им комплексным кремне-кислородным радикалом. Силикаты выступают здесь важнейшими породообразующими минералами глин, песков, суглинков, супесей, песчаников, гранитов.

Широкое распространение силикатных горных пород, участвующих в строении литогенной основы ландшафтов рассматриваемого региона, связано с морскими и континентальными отложениями, среди которых доминируют лессовидные маломощные безвалунные суглинки, перекрывающие на обширной территории различные элементы рельефа. В области Донского ледникового языка распространена морена - глины и суглинки, в разной степени обогащенные местными и эрратическими валунами [Грищенко, 1976].

Формирование чехла осадочных силикатных горных пород тесно связано с природными условиями литогенеза палеогена, неогена и четвертичного периода, в итоге предопределившими различия литогенной основы и дифференциации ландшафтов. Распространение, генезис, состав толщи осадочного чехла каждого геологического этапа их развития существенно отличаются.

Палеогеновые отложения перекрывают водоразделы Среднерусской и Калачской возвышенности. Мощность их возрастает от нескольких метров на севере до 150 м на югозападе региона. Они включают терригенные, органогенные и хемогенные породы. Доминируют породы терригенного типа, состоящие преимущественно из кварцевых песков и разнообразных глин [Семенов, 1965].

Неогеновые отложения наиболее полно представлены на территории ОкскоДонской низменности. Неогеном здесь выполнен ряд субмеридиональных эрозионных долин, включающих аллювиальные и лиманно-морские отложения [Семенов, 1965].

Четвертичные отложения представлены тремя формациями: аллювиальной, ледниковой и лессово-почвенной, или субаэральной, включающими аллювиальные и делювиальные отложения 3-й и 4-й надпойменных террас (пески, суглинки, глины), флювиогляциальные отложения (пески, глины), аллювиальные отложения пойм и 1-й и 2-й надпойменных террас (пески, суглинки, глины), гляциальные (морена, пески, суглинки, глины), перигляциальные отложения водоразделов, пролювиально-делювиальные отложения склонов во внеледниковой области (суглинки) [Холмовой, 2013].

На территории Центрального Черноземья силикатные горные породы образуют три основных типа литогенной основы ландшафтов: песчаный, суглинистый, глинистый. В зависимости от различий генезиса, состава и свойств в каждом типе литогенной основы обособились структурные элементы (подтипы). Песчаный тип включает аллювиальный и флювиогляциальный подтипы отложений; суглинистый - лессовидный и моренный; глинистый - осадочно-морской и ледниково-моренный.

Неоднородность субстрата предопределила разнообразие почвенно-растительного покрова и ландшафтов территории распределения силикатных горных пород, образующих литогенную основу региона. На суглинистом субстрате сформировались дубравные и разнотравно-злаковые комплексы, на песках - песчаные степи и сосновые леса, в местах при- 
поверхностного залегания глинистых отложений развитие получили дубово-ивняковоосинниковые группировки.

Все это свидетельствует о достаточно широком спектре и значимом проявлении ландшафтообразующей роли литогенной основы исследуемой территории. Однако слабая изученность региональных особенностей литоландшафтогенеза затрудняет решение ряда задач, связанных преимущественно с рациональным природопользованием. Это предопределяет необходимость проведения специальных исследований с целью установления прежде всего структурно-генетической организации и ландшафтообразующей функции литогенной основы Центрального Черноземья.

Структурно-генетическая классификация литогенной основы ландиафтов. Разнообразие литологических формаций Центрального Черноземья предопределяет различия литоландшафтогенеза и, как следствие, формирование различных по структуре и генезису ландшафтов. Установление строения, свойств, дифференциации и особенностей развития литогенной основы представляет как научный, так и практический интерес. В частности, получение информации о природной специфике литогенной основы позволяет расширить представления о региональных особенностях проявления литоландшафтогенеза, тенденциях развития ландшафтов, их устойчивости и потенциале. Внедрение этих знаний в практику, например, природопользования способствовало бы более обоснованному в научном отношении решению задач, связанных с рациональным использованием природных ресурсов, территориальным планированием, ландшафтно-экологическим проектированием, совершенствованием сети особо охраняемых территорий.

Однако разрозненность данных о составе, свойствах, структуре и генезисе литогенной основы, а также отсутствие систематизации ее элементов затрудняют реализацию этих задач. Принимая это во внимание, авторами предпринята попытка разработать структурно-генетическую классификацию элементов литогенной основы Центрального Черноземья.

Предлагаемая классификация выполнена на основе типологической группировки литологических формаций региона. По своей сути это типологическая группировка структурных элементов литогенной основы по сходству физико-механических и химических свойств, а также общности их литологического строения и генезиса.

Высшей таксономической единицей классификации принят отдел, в основу выделения которого положена общность механического состава горных пород литогенной основы. В регионе выделено два отдела литогенной основы: петрогенный и пелитовый. Учитывая химический состав доминирующих ландшафтообразующих горных пород, отделы подразделены на классы: карбонатный и силикатный, в рамках которых на основе различий литологического состава горных пород вычленены типы литогенной основы (известняковый, меловой, мергельный, суглинистый и др.). Генетические и геоморфологические особенности литогенной основы послужили критерием обоснования таксонов на уровне рода, варианта и вида (табл. 2.).

Литогенная основа как фактор дифференциации и разнообразия ландиафтов. Геологическое строение и рельеф совместно формируют литогенную основу и придают ей индивидуальность, проявляющуюся в дифференциации и разнообразии ландшафтов Центрального Черноземья. Литогенная основа здесь играет очень большую роль в обособлении региональных и типологических ландшафтных комплексов. Особенно убедительно это показано в работах, посвященных физико-географическому районированию и ландшафтному картографированию региона [Физико-географическое..., 1961; Экологогеографические..., 1996]. 
Структурно-генетическая классификация литогенной основы ландшафтов Центрального Черноземья

Structural and genetic classification of the lithogenic basis of landscapes

of the Central Chernozems Region

\begin{tabular}{|c|c|c|c|c|c|}
\hline Таксон & Основание & \multicolumn{4}{|c|}{ Литолого-геоморфологические особенности } \\
\hline Отдел & $\begin{array}{l}\text { Механический } \\
\text { состав горных }\end{array}$ & \multicolumn{2}{|c|}{$\begin{array}{l}\text { Петрогенный, плотный, } \\
\text { щебнисто-глыбовый }\end{array}$} & \multicolumn{2}{|c|}{$\begin{array}{c}\text { Пелитовый, рыхлый, } \\
\text { мелкозернистый }\end{array}$} \\
\hline Класс & $\begin{array}{c}\text { Химический } \\
\text { состав горных } \\
\text { пород }\end{array}$ & Карбонатный & Силикатный & Карбонатный & Силикатный \\
\hline Тип & $\begin{array}{c}\text { Литологичес-кий } \\
\text { состав горных } \\
\text { пород }\end{array}$ & $\begin{array}{c}\text { Известняко- } \\
\text { вый } \\
\text { Меловой } \\
\text { Мергельный } \\
\text { Доломитовый }\end{array}$ & $\begin{array}{l}\text { Песчаниковый } \\
\text { Гранитный }\end{array}$ & $\begin{array}{c}\text { Меловой } \\
\text { Мергельный } \\
\text { Доломитовый }\end{array}$ & $\begin{array}{c}\text { Песчаный } \\
\text { Суглинистый } \\
\text { Глинистый }\end{array}$ \\
\hline Род & $\begin{array}{c}\text { Генезис горных } \\
\text { пород }\end{array}$ & $\begin{array}{l}\text { Осадочно- } \\
\text { морской }\end{array}$ & $\begin{array}{c}\text { Осадочно- } \\
\text { морской } \\
\text { Магматический }\end{array}$ & $\begin{array}{l}\text { Денудационно- } \\
\text { аккумулятивный }\end{array}$ & $\begin{array}{l}\text { Континетально- } \\
\text { осадочный }\end{array}$ \\
\hline Вариант & $\begin{array}{c}\text { Гипсометри- } \\
\text { ческие } \\
\text { различия }\end{array}$ & \multicolumn{4}{|c|}{$\begin{array}{c}\text { Высотные уровни: } \\
\text { Высокий } \\
\text { Низкий }\end{array}$} \\
\hline Вид & $\begin{array}{c}\text { Морфоскульп- } \\
\text { тура литогенной } \\
\text { основы }\end{array}$ & \begin{tabular}{|c|} 
Эрозионная \\
Оползневая \\
Карстовая \\
Суффозионная \\
Мерзлотная \\
Антропогенная
\end{tabular} & $\begin{array}{c}\text { Эрозионная } \\
\text { Антропогенная }\end{array}$ & $\begin{array}{c}\text { Эрозионная } \\
\text { Оползневая } \\
\text { Карстовая } \\
\text { Суффозионная } \\
\text { Аккумулятивная } \\
\text { Антропогенная }\end{array}$ & $\begin{array}{c}\text { Эрозионная } \\
\text { Оползневая } \\
\text { Суффозионная } \\
\text { Аккумулятивная } \\
\text { Антропогенная }\end{array}$ \\
\hline
\end{tabular}

Все региональные ландшафтные комплексы (зональные области, провинции, районы) несут на себе воздействие литогенного фактора. Однако ландшафтообразующая роль его в рамках таксономических единиц проявляется неодинаково и зависит от соотношения с другими факторами - тектогенным, климатогенным, биогенным, антропогенным. С уменьшением таксономического ранга региональных комплексов наблюдается усиление ландшафтообразующей роли литогенной основы. На уровне самых низких таксономических единиц (физико-географических районов) литогенная основа нередко играет ведущую роль в их обособлении. Например, в генетическом отношении физикогеографические районы Донского Белогорья (Придонской меловой, Калитвинский волнисто-балочный, Богучарский правобережный степной) относятся к литогенному (петрогенному) ряду ландшафтных комплексов [Донское..., 1976].

Ведущая роль литогенной основы в формировании и обособлении типологических ландшафтных комплексов - фаций, урочищ, типов местности - нашла широкое отражение в работах многих исследователей. Убедительно показана зависимость дифференциации ландшафтов от литогенного фактора. На основе учета местоположения в рельефе и литологии материнских пород выделены типы местности региона (плакорный, междуречный недренированный, зандровый, останцово-водораздельный, склоновый, пойменный), внутреннее ландшафтное различие которых раскрыто на уровне литологических и высотногеоморфологических вариантов типов местности, получивших наиболее детальное отражение на ландшафтной карте Воронежской области (1:200 000). 
Для Центрального Черноземья все большую актуальность приобретает проблема сохранения и увеличения ландшафтного разнообразия - важнейшего фактора устойчивого и оптимального ландшафтно-экологического состояния региона. Решение ее возможно на основе четких представлений о региональных особенностях формирования ландшафтного разнообразия под воздействием литогенного фактора. Получение такого рода информации будет способствовать увеличению ландшафтного разнообразия путем создания оптимальной ландшафтно-экологической сети Центрального Черноземья на основе учета ландшафтообразующей роли литогенной основы.

Свидетельством в пользу эффективности оптимизации экологической обстановки путем управления ландшафтным разнообразием может служить результат эксперимента по борьбе с засухами на территории Каменной Степи при помощи создания фитомелиоративных и обводнительных мелиоративных систем. В результате опытных работ здесь существенно изменилась ландшафтно-экологическая обстановка, сформировался идеально оптимизированный южнолесостепной лесо-аграрный ландшафт.

Таким образом, ландшафтообразующая роль литогенной основы в пределах Центрального Черноземья проявляется достаточно своеобразно. В зависимости от состава свойств и местоположения горных пород в рельефе, а также соотношения с интеграциями современных источников развития ландшафтов, воздействия их на физикогеографические процессы и компоненты проявляются неоднозначно. Это предопределяет особенности формирования и дифференциации ландшафтов. В этой связи учет специфики ландшафтообразующей роли литогенной основы важен при решении научных и практических задач, касающихся природопользования и оптимизации ландшафтно-экологической обстановки региона.

\section{Заключение}

Результаты проведенных исследований свидетельствуют о том, что генезис, формирование, дифференциация, развитие и структурная организация ландшафтов Центрального Черноземья в значительной мере зависят от литогенной основы (геологического строения и рельефа). Это предопределяет актуальность изучения и учета в практике региональных особенностей литоландшафтогенеза.

В процессе исследований установлено, что ландшафтообразующая роль литогенного фактора в пределах рассматриваемого региона проявляется повсеместно. Однако, в зависимости от соотношения литогенной основы с интеграциями современных источников ландшафтогенеза, она варьирует от ведущей до подчиненной. При ведущей роли, получившей наименование «литоландшафтогенеза», формируются природные комплексы особой категории - литогенные (петрогенные) ландшафты.

Дифференцированный характер литоландшафтогенеза тесно связан со строением и свойствами литогенной основы. В строении литогенной основы ландшафтов Центрального Черноземья принимают участие две основные группы осадочных горных пород: карбонатные и силикатные. Различия физико-механических и химических свойств пород проявляются в энерго- и массообмене вещества, участвующего в ландшафтогенезе. В результате создаются предпосылки для развития и дифференциации ландшафтов, формирования их разнообразия и устойчивости. Все это находит отражение в структурно-генетической организации ландшафтов Центрального Черноземья.

Анализ региональных особенностей проявления литоландшафтогенеза, а также картографирование и классификация структурных элементов литогенной основы ландшафтов Центрального Черноземья позволяют сделать вывод о высокой степени дифференциации ландшафтообразующей роли карбонатных и силикатных горных пород региона. Это предопределяет своеобразие развития, формирования разнообразия и устойчиво- 
сти ландшафтов. Учет этих особенностей литоландшафтогенеза способствовал бы более глубокому обоснованию приемов природопользования и оптимизации ландшафтноэкологической обстановки Центрального Черноземья.

\section{Список литературы}

1. Быковская О.П., Михно $\quad$ В.Б., Горбунов А.С., Бевз В.Н. 2015. Ледовый литоландшафтогенез и его проявление в ландшафтной структуре Центрального Черноземья. Материалы всероссийской конференции «Марковские чтения 2015 года». Москва, Изд-во географического факультета Московского государственного университета: 46-48.

2. Грищенко М.Н. 1976. Плейстоцен и голоцен бассейна Верхнего Дона. М., Наука, 229 с.

3. Дмитриев Д.А., Савко А.Д., Жабин А.В. 2004. Сантонские отложения правобережья среднего течения реки Дон. Труды научно-исследовательского института геологии Воронежского государственного университета, 21: 1-104.

4. Донское Белогорье. 1976. Под. ред. Ф.Н. Милькова. Воронеж, Изд-во Воронежского государственного университета, 160 с.

5. Известняковый север Среднерусской возвышенности. 1978. Под. ред. Ф.Н. Милькова. Воронеж, Изд-во Воронежского государственного университета, 178 с.

6. Иванова Е.О., Савко А.Д. 2011. Верхнемеловые отложения юго-запада ЦЧЭР (Белгородская и Курская области). Труды научно-исследовательского института геологии Воронежского государственного университета, 64: 1-93.

7. Мильков Ф.Н. 1977. Генезис и генетические ряды ландшафтных комплексов. В кн.: Землеведение. Сборник Московского общества испытателей природы. Новая серия. Т. 12. М., Издво Московского университета: 5-11.

8. Мильков Ф.Н. 1986. Физическая география: учение о ландшафте и географическая зональность. Воронеж, Изд-во Воронежского государственного университета, 328 с.

9. Михно В.Б. 1990. Карстово-меловые геосистемы Русской равнины. Воронеж, Изд-во Воронежского государственного университета, 200 с.

10. Михно В.Б. 1999. Литоландшафтогенез, его сущность и специфика. Вестник Воронежского отдела Русского географического общества, 1 (1): 1-7.

11. Михно В.Б., Горбунов А.С. 2019. Ландшафтогенез карбонатных пород верхнемеловых отложений Воронежской антеклизы. Вестник Воронежского государственного университета. Сер. Геология, 2: 5-14.

12. Николаев В.А. 2006. Ландшафтоведение. М., Изд-во Географического факультета Московского государственного университета, 208 с.

13. Перельман А.И. 1975. Геохимия ландшафта. М., Высшая школа, 342 с.

14. Савко А.Д., Мануковский С.В., Мизин А.И., Бурыкин В.Н, Бартенев В.К., Бабкин В.Ф., Окороков В.А. 2001. Литология и фации донеогеновых отложений Воронежской антеклизы. Труды научно-исследовательского института геологии Воронежского государственного университета, 3: 201.

15. Семенов В.П. 1965. Палеоген Воронежской антеклизы. Воронеж, Изд-во Воронежского государственного университета, $280 \mathrm{c.}$

16. Солнцев Н.А. 2001. Учение о ландшафте (избранные труды). М., Изд-во Московского университета, $384 \mathrm{c.}$

17. Страхов Н.М. 1960. Основы теории литогенеза. Т. 1. Типы литогенеза и их размещение на поверхности Земли. М., Изд-во АН СССР, 212 с.

18. Физико-географическое районирование Центрально-Черноземных областей. 1961. Под. ред. Ф.Н. Милькова. Воронеж, Изд-во Воронежского государственного университета, 261 с.

19. Холмовой Г.В. 2013. Геологическая карта дочетвертичных отложений. В кн.: Экологогеографический Атлас-книга Воронежской области. Воронеж, Изд-во Воронежского государственного университета: 40-42.

20. Эколого-географические районы Воронежской области. 1996. Под. ред. Ф.Н. Милькова. Воронеж, Изд-во Воронежского государственного университета, 216 с. 


\section{References}

1. Bykovskaya O.P., Mihno V.B., Gorbunov A.S., Bevz V.N. 2015. Ledovyj litolandshaftogenez i ego proyavlenie v landshaftnoj strukture Central'nogo Chernozem'ya. Materialy vserossijskoj konferencii «Markovskie chteniya 2015 goda». [Ice litholandscape genesis and its manifestation in the landscape structure of the Central Black Earth Region. Materials of the Russian Conference «Markov Readings of 2015»]. Moscow, Izd-vo Geograficheskogo fakul'teta Moskovskogo gosudarstvennogo universiteta: $46-48$.

2. Grishchenko M.N. 1976. Plejstocen i golocen bassejna Verhnego Dona [Pleistocene and Holocene of the Upper Don Basin]. Moscow, Nauka, 229 p.

3. Dmitriev D.A., Savko A.D., Zhabin A.V. 2004. Santonian deposits of the right bank of the middle reaches of the Don River. Proceedings of the Research Institute of Geology of the Voronezh State University, 21: 1-104. (in Russian)

4. Donskoe Belogor'e [Don Belogorye]. 1976. Ed. Mil'kov F.N. Voronezh, Izd-vo Voronezhskogo gosudarstvennogo universiteta, $160 \mathrm{p}$.

5. Izvestnyakovyj sever Srednerusskoj vozvyshennosti [Limestone north of the Central Russian Upland]. 1978. Ed. Mil'kov F.N. Voronezh, Izd-vo Voronezhskogo gosudarstvennogo universiteta: 178 p. (in Russian)

6. Ivanova E.O., Savko A.D. 2011. Upper Cretaceous deposits of the south-west of the Central Chernozems Economic Region (Belgorod and Kursk Regions). Proceedings of the Research Institute of Geology of the Voronezh State University, 64: 1-93. (in Russian)

7. Mil'kov F.N. 1977. Genesis and genetic series of landscapes. Earth Research. In: Collected articles of the Moscow Society of Naturalist. New Series. Vol. 12. Moscow, Moscow University Press: 5-11. (in Russian)

8. Mil'kov F.N. 1986. Fizicheskaya geografiya: uchenie o landshafte i geograficheskaya zonal'nost' [Physical Geography: Study of landscape and geographical zonality]. Voronezh, Izd-vo Voronezhskogo gosudarstvennogo universiteta, $328 \mathrm{p}$.

9. Mihno V.B. 1990. Karstovo-melovye geosistemy Russkoj ravniny [Karst-Cretaceous geosystems of the Russian Plain]. Voronezh, Izd-vo Voronezhskogo gosudarstvennogo universiteta, 1990, $200 \mathrm{p}$.

10. Mihno V.B. 1999. Litolandshaftogenez, ego sushchnost' i specifika. [Lithological genesis of landscapes, its essence and specificity]. Vestnik Voronezhskogo otdela Russkogo geograficheskogo obshchestva, 1(1): 1-7.

11. Mihno V.B., Gorbunov A.S. 2019. Landscapes genesis of carbonate rocks of the upper cretaceous deposits of the Voronezh anteclise. Proceedings of Voronezh State University. Series: Geology, 2: 5-14. (in Russian)

12. Nikolaev V.A. 2006. Landshaftovedenie. [Landscape science]. Moscow, Izd-vo Geograficheskogo fakul'teta Moskovskogo gosudarstvennogo universiteta, 208 p.

13. Perel'man A.I. 1975. Geohimiya landshafta [Landscape geochemistry]. Moscow, Vysshaya shkola, $342 \mathrm{p}$.

14. Savko A.D., Manukovskij S.V., Mizin A.I., Burykin V.N, Bartenev V.K., Babkin V.F., Okorokov V.A. 2001. Lithology and facies of pre-Neogene deposits of the Voronezh anteclise. Proceedings of the Research Institute of Geology of the Voronezh State University, 3: 201. (in Russian)

15. Semenov V.P. 1965. Paleogen Voronezhskoj anteklizy [Paleogene of the Voronezh anteclise]. Voronezh, Izd-vo Voronezhskogo gosudarstvennogo universiteta, $280 \mathrm{p}$.

16. Solncev N.A. 2001. Uchenie o landshafte (izbrannye trudy) [Study of landscape: (selected works)]. Moscow, Moscow University Press, 384 p.

17. Strahov N.M. 1960. Osnovy teorii litogeneza. T.1. Tipy litogeneza i ih razmeshchenie na poverhnosti Zemli. [Fundamentals of the theory of lithogenesis. Vol. 1. Types of lithogenesis and its location on the Earth surface]. Moscow, Izdatel'stvo AN SSSR, 212 p.

18. Fiziko-geograficheskoe rajonirovanie Central'no-Chernozemnyh oblastej [Physicalgeographical zoning of the Central Chernozems Regions]. 1961. Ed. Mil'kov F.N. Voronezh, Izd-vo Voronezhskogo gosudarstvennogo universiteta, $261 \mathrm{p}$. 
19. Holmovoj G.V. Geological map of pre-Quaternary sediments. In: Ecological and geographical Atlas-book of the Voronezh region. Voronezh, Izd-vo Voronezhskogo gosudarstvennogo universiteta: 40-42. (in Russian)

20. Ekologo-geograficheskie rajony Voronezhskoj oblasti [Ecological and geographical district of the Voronezh region]. 1996. Ed. Mil'kov F.N. Voronezh, Izd-vo Voronezhskogo gosudarstvennogo universiteta, $216 \mathrm{p}$.

\section{ИНФОРМАЦИЯ ОБ АВТОРЕ}

Михно В.Б., профессор, доктор географических наук, профессор кафедры физической географии и оптимизации ландшафта Воронежского государственного университета, г. Воронеж, Россия

Быковская О.П., доцент, кандидат географических наук, заведующий кафедрой физической географии и оптимизации ландшафта Воронежского государственного университета, г. Воронеж, Россия

Горбунов А.С., кандидат географических наук, доцент кафедры физической географии и оптимизации ландшафта Воронежского государственного университета, г. Воронеж, Россия

\section{INFORMATION ABOUT THE AUTHOR}

Vladimir B. Mikhno, professor, doctor of geographical Sciences, Professor of the Department of physical geography and landscape optimization, Voronezh state University, Voronezh, Russia

Ol'ga P. Bykovskaya, associate Professor, candidate of geographical Sciences, head of the Department of physical geography and landscape optimization of Voronezh state University, Voronezh, Russia

Anatoliy S Gorbuno., candidate of geographical Sciences, associate Professor of the Department of physical geography and landscape optimization of Voronezh state University, Voronezh, Russia 